\begin{tabular}{|c|c|c|}
\hline PORT SAID ENGINEERING RESEARCH JOURNAL \\
Faculty of Engineering - Port Said University \\
Volume 17 No. 2 September 2013 pp: 18 - 29
\end{tabular}

\title{
Flow Field and Combustion Characteristics of Natural Gas inside a Gas Turbine Combustor
}

\author{
Ibrahim, I. A. ${ }^{{ }^{*},}$ Farag, T. M. ${ }^{1}$, Shehata, M. A. ${ }^{1}$ and Shabaan, M. M. ${ }^{1}$
}

\begin{abstract}
The present work is numerical simulation results from the modeling of a non-premixed natural gas flame performed in a combustor model. CFD studies using FLUENT code were carried out for different air swirl numbers and inlet thermal load with constant A/F. The isothermal flow field was simulated using (SST) $k-\omega$ turbulence model and the reacting flow was simulated by the non-premixed combustion model with the P-1 radiation model available in the computational fluid dynamics package Fluent 6.3. The model geometry was created and meshing arrangement was generated using Gambit pre-processing software. The domain of the model was based on the dimension of the combustor and burners. The case studied is a cylindrical enclosure of $0.1 \mathrm{~m}$ radius and $1.0 \mathrm{~m}$ length. Two reactant streams emerge from two separate coaxial jets producing a swirling diffusion flame. The natural gas is issued axially into the combustor from the annulus area between the swirler outer diameter and the burner hub diameter whereas the combustion air is introduced through an annular swirler having uniform swirl vanes. The results show a reasonable agreement of the measured and the calculated reverse flow zone sizes using the shear stress transport (SST) k- $\omega$ model. The boundary of the reverse flow zone for weak air swirl nu mber of 0.5 is formed completely inside the co mbustor with closed loop, while for air swirl numbers of 0.87 and 1.5 the boundaries fill the combustor and its size increased as the air swirl nu mber increased. Increasing the air swirl number, the high temperature regions size, the flame length, and the $\mathrm{CO}_{2}$ and $\mathrm{CO}$ concentrations decreased while the $\mathrm{O}_{2}$ concentration increased. Increasing the thermal load, the high temperature reg ions size, the flame length, $\mathrm{CO}_{2}$ and $\mathrm{CO}$ concentrations increased, while the $\mathrm{O}_{2}$ concentration decreased.
\end{abstract}

KEYWORDS: Swirl number, Gas turbine combustor, Diffusion flame, Reverse flow zone and Natural gas combustion.

\section{INTRODUCTION}

Diffusion flames have been widely applied in industrial process systems, such as burners and furnaces. Both numerical and experimental investigations of turbulent diffusion (non-premixed) flames have been the subject of extensive research during recent years for several gas fuels and liquid fuels, because they are very important for the understanding of complex interactions between the turbulent flow and chemical reactions.

Computational fluid dynamics (CFD) represents an economic and reliable tool for facilitating the combustion system design. Computational fluid dynamics (CFD) has proven being a valuable tool in optimizing combustion equipments and especially natural gas burners. The standard k- $\varepsilon$ and the RSM models have been employed for extensive numerical studies. Presently, the most widely used turbulence model in computational fluid dynamics (CFD) codes is the standard k- $\varepsilon$ model.

There are several commercial software packages applied widely in research and development. For the

\footnotetext{
1 Department of Mechanical Power Engineering, Faculty of Engineering, Port Said University, Egypt

*Corresponding author: hema bb76@yahoo.com
}

simulation of a turbulent non-premixed flame, several models are available. Thermal radiation in gaseous media can be an important mode of heat transfer in high temperature combustion systems, such as combustors, furnaces and fires. Radiation exchange plays a very important role even under non-soot conditions $[1,2]$.

The performance of the discrete transfer and six flux radiation models in a swirling natural gas diffusion flame in axisymmetric furnace was confined by Keramida et al [3]. Computational results with and without radiation effects are compared with experimental data. The results have demonstrated that the effect of thermal radiation is important even in light flames, and that the six flux model can be applied in industrial gas furnaces with relative ease, yielding accurate predictions.

A numerical simulation results from the modeling of turbulent non-premixed hydrogen - hydrocarbon flame with and without radiation models was presented by Mustafa [4]. The model results are compared with each other and with experimental data. Ilbas investigated the effect of fuel composition from pure natural gas to hydrogen. The standard k- $\varepsilon$ model was used for the modelling of the turbulence phenomena in the combustor. 
The numerical simulation of a turbulent non-premixed hydrogen diffusion flame in a model combustor was performed by Ilbas et al [5]. The model prediction studies have been extended to combustion air staging. Air $25 \%$ was staged and introduced through the two tangential inlets. The temperature and major pollutant concentration (CO and NOx) distributions are in good agreement with experimental measurements. The overall flame temperature increases as hydrogen is added or decrease as methane is added to the fuel mixture. The addition of methane to hydrogen decreases the flame temperature and thus NOx emissions through the combustion exit.

A numerical simulation results from the modelling of a non-premixed methane flame with and without radiation models were presented by Ibrahim and Shabaan [6]. CFD studies using FLUENT code were carried out for three cases; without radiation model, with the $\mathrm{P}-1$ radiation model and with the discrete transfer radiation model. The discrete transfer and of the $\mathrm{P}-1$ radiation models are assessed in a swirling methane non-premixed flame confined in an axisymmetric combustor. They have demonstrated that the effect of thermal radiation is important even in flames, and that the discrete transfer and the $\mathrm{P}-1$ radiation models and realizable $\mathrm{k}-\varepsilon$ turbulent model can be applied in industrial gas furnaces with relative ease, yielding accurate predictions. A review of the most commonly used methods to predict radiative heat transfer in combustion chambers is presented by Carvalho and Farias [7].

Results obtained by German and Mahmud [8] showed good agreement between the measurements and the predictions obtained with both the $\mathrm{k}-\varepsilon$ and Reynoldsstress turbulence models. Direct comparison of measured and computed flow patterns led to the conclusion that in the analyzed cases the Reynolds stress model was far superior to the widely used k- $\varepsilon$ model as discussed by Weberet al [9]. However, the obtained numerical results show that some modifications to the RSM model are required to improve further predictions of the axial velocity distributions.

A presumed probability density function (PDF) model for temperature fluctuation is proposed and formu lated by Peng and Zhang [10]. It incorporates a two-step reaction mechanis $\mathrm{m}$ for propane combustion mechanism. Their model, together with a new algebraic Reynolds stress model (RSM), is employed to simulate the turbulent combustion in a swirl combustor. They found that the calculated carbon monoxide, and carbon dioxide concentrations agree with the measurement. The calculated gas temperature and oxygen concentrations are in general agreement with the measured data.

Computational fluid dynamics simulations in a swirl combustor were coupled with chemical equilibrium calculations to evaluate the effects of swirl velocity and burner wall temperature on NOx formation. Khanafer and Aithal [11] develop a fast and robust computational approach to understand the impact of various design parameters on Nox formation in gas-fired swirl burners.
The results showed that increasing swirl reduced $\mathrm{CO}$ and unburned hydrocarbons. The exit plane NOx did not decrease with increasing swirl. NOx values initially increased with increasing swirl and then decreased.

The numerical prediction of a high swirling nonpremixed confined natural gas diffusion flame in order to predict the pollutant emissions NOx using the PDF model coupled with the Reynolds stress model (RSM) was studied by Khelila et al [12]. A chemical equilibrium model in conjunction with the assumed shape of the PDF is adopted. The PDF of the mixture fraction is described with a $\beta$-function. In order to predict the NOx emissions, a NOx post-processor of the Fluent code has been performed. They obtained the concentration of $\mathrm{O}$ and $\mathrm{OH}$ radicals assuming the partial-equilibrium assumption and using a PDF in terms of temperature. The numerical simulation of various factors influencing the combustion process are examined and compared favourably with experimental results.

The standard k- $\varepsilon$ model, the realizable k- $\varepsilon$ model, the standard k- $\omega$ model and the Reynolds Stress model (RSM) in Fluent were used by Jian et al. [13] to predict the turbulent combustion reaction in a methane/air diffusion flame. The results indicated that the simulation of velocities, temperatures and exhaust gas concentrations of combustion products by the standard k- $\varepsilon$ model were in good agreement with the experimental results. Related to the experimental conditions, the standard $\mathrm{k}-\omega$ model gives good prediction. So, it is a reasonable model for the simulation of a methane/air turbulent-jet diffusion flames.

A numerical and experimental investigation of strongly swirling flow in a water model combustion chamber was described by Xia. et al [14]. The turbulence models used for the numerical calcu lations are the standard k- $\varepsilon$ model, the RNG k- $\varepsilon$ model and Reynolds stress model (RSM). They found that the Reynolds Stress Model (RSM) captured all the major features of the swirling flow while both the standard k- $\varepsilon$ and the Renormalized Group (RNG) $\mathrm{k}-\varepsilon$ models did not because they do not properly account for the interaction between the swirl and the turbulence.

The numerical calculations of flame temperature and species concentrations in methane/air non-premixed flames using the standard $\mathrm{k}-\varepsilon$ model for modeling the flow field and a probability density function (PDF) for the scalar fields was performed by Amani and Nobari [15]. Simulation was also done by Reynolds Average Naveir Stockes Equations (RANS). The predicted temperature has $26 \%$ error via RANS method and $8 \%$ error via the PDF method. Also it predicts that the total heat released in methane combustion in a very good agreement with the experiment.

From the most published researches, the standard k- $\varepsilon$ model performs poorly for flows with larger pressure gradient, strong separation, high swirling component and large streamline curvature. In the present study, an effort to use the shear stress transport (SST), which is suitable and applicable for complex boundary layer flows under adverse pressure gradient, high swirling component and 
separation, to validate and consequently the flow field and combustion characteristics of natural gas inside a gas turbine combustor is simulated. The effect of air swirl number and the inlet thermal load on the flow field and combustion characteristics is studied theoretically. Validation of the calculation is done by comparing the CFD simulation results with the experimental ones. Three air swirl numbers are used it takes the values of $0.50,0.87$ and 1.5. The effect of air swirl numbers on the RFZ, the axial velocity distribution and turbulence in a gas turbine combustor will be investigated.

\section{TURBULENCE MODEL}

FLUENT provides the shear stress transport (SST) k- $\omega$ model, which was developed by Menter [16]. It is so named because the definition of the turbulent viscosity is modified to account for the transport of the principal turbulent shear stress. The SST k- $\omega$ model has an advantage in terms of performance over both the standard $\mathrm{k}-\omega$ model and the standard $\mathrm{k}-\varepsilon$ model. Other modifications include the addition of a cross-diffusion term in the $(\omega)$ equation and a blending function to ensure that the model behaves appropriately in both the near-wall and far-field zones [17].

\section{COMPUTATIONAL DETAILS}

\subsection{Combustor Configuration}

The domain of the model was based on the dimension of the combustor and burners. The case studied is a cylindrical enclosure of $0.1 \mathrm{~m}$ radius and $1.0 \mathrm{~m}$ length. Two reactant streams emerge from two separate coaxial jets producing a swirling diffusion flame. The natural gas is issued axially into the combustor from the annulus area between the swirler outer diameter and the burner hub diameter whereas the combustion air is introduced through an annular swirler having uniform swirl vanes. The hub and outer diameters are 72 and $100 \mathrm{~mm}$ respectively, the setting vane angles are: $30^{\circ}, 45^{\circ}$ and $60^{\circ}$ were manufactured to generate swirling motion of swirl number (S) 0.5, 0.87 and 1.5, respectively. The geometry of this furnace is illustrated in Fig.1.

\subsection{Grid System and Mesh Independence}

Figure 1 shows the domain which used to simulate the combustor. The domain consists of an axisymmetric plane has the dimensions of the combustor. The region of interest is that just above the exit of the burner. An unstructured grid has been created using the GAMBIT pre-processor to discretize the computational domain [18]. The cell type used is the Quad-Map cell, the grid lines were non-uniformly spaced on both radial and axial directions as shown in Fig. 2. Grid independence tests for four different mesh sizes of $60 \times 300,70 \times 300,80 \times 300$ and $80 \times 310$ cells were carried out. The influence of the mesh refinement on the distribution of velocity (cold flow) and the temperature along the axis of the combustor are shown in Fig. 3 and Fig.4, respectively. The results indicate that increasing the grid size from $60 \times 300$ to $80 \times 310$ cells has lead to around $(0.5-3.5 \%)$ difference in the axial velocity and about $1 \%$ in the axial temperature. Considering the computational expense and time, the grid with $70 \times 300$ cells is considered for further analysis since the flow parameters are found to be independent of mesh size. Thus, the mesh of $70 \times 300$ cells was considered suitable for the present calculations.

\section{VALIDATION OF COMPUTATION}

In order to validate the computational procedure, comparison of the present calculations with the experimental data was performed. The experimental data were obtained for the combustion process inside combustor of radious of $0.1 \mathrm{~m}$ and $1.0 \mathrm{~m}$ length. Natural gas at a velocity of $3.2 \mathrm{~m} / \mathrm{s}(\mathrm{A} / \mathrm{F}=40)$. was burned with air at an axial velocity of $5.5 \mathrm{~m} / \mathrm{s}$ with swirl number of 0.87. Comparisons were made between the experimental data and the calculated results obtained with standard k$\varepsilon$ and Shear-stress transport (SST) k- $\omega$ models. The axial temperature profiles are shown in Fig.5.a. It is shown that, computational analysis using Shear-Stress Transport (SST) k- $\omega$ model has produced better agreement between the predictions and the experimental data than that for Standard k- $\varepsilon$ model, so in the present study (SST) k- $\omega$ model was used. The radial temperature profiles at different locations $\mathrm{x}=0.5,0.7$ and $0.95 \mathrm{~m}$ are shown in Fig.5.a, using this (SST) k- $\omega$ model.

The reverse flow zones for open end combustor are shown in Fig. 5.b. The results from the computational fluid dynamics (CFD) calculations which are compared with that obtained from the experimental data [19] for verify ing the turbulence model used. Predictions from the SST k- $\omega$ model presented a reasonable agreement with the experimental data. Due to the reasonable agreement obtained between the computational results and the experimental measurements of the reverse flow zones.

Comparing the obtained results, the SST-k- $\omega$ model provided acceptable results that agree with the experimental measurements and the closest to the standard k- $\varepsilon$ model results. Also, less time was consumed reaching convergent solution when using the SST k- $\omega$ model than that when using the RSM model. The SST k- $\omega$ model is selected for turbulence modeling. Therefore, the SST k- $\omega$ is selected for performing further numerical analysis needed for the present study. Since heat transfer occurs in the system considered here, the energy equation is enabled. There are many radiation models that can produce accurate solutions but they can be computational expensive.

The P-1 radiation model available in Fluent 6.3 is selected for the present simulation as it produces a quick and acceptable solution in case of non-premixed combustion modeling [4, 5]. The effect of thermal radiation is important even in flames, and that the discrete transfer and the $\mathrm{P}-1$ radiation models and realizable k- $\varepsilon$ turbulent model can be applied in industrial gas furnaces 
with relative ease, yield ing accurate predictions, this was demonstrated by $[4,6]$.

\section{RESULTS AND DISCUSSION}

In this session, the calculated results are discussed. The effect of only two parameters is investigated, the air swirl number which takes the values of $0.50,0.87$ and 1.50 , and the fuel mass flow rate which takes the values of $0.4,0.5$ and $0.6 \mathrm{~g} / \mathrm{s}$ corresponding to thermal loads of 20, 25 and $30 \mathrm{~kW}$ respectively. The effect of air swirl number on is othermal flow field and the natural gas combustion characteristics are investigated. These combustion characteristics include radial and axial temperature distribution inside the combustor (temperature maps), centreline (axial) temperature distributions and exhaust species concentrations.

The aerodynamic study of the is othermal flow inside a gas turbine combustor is very relevant to the combustion process. Therefore, detailed information about the is othermal flow field must be known to enable understanding of the parameters that affect the combustion process $[20,21]$. Therefore, one of the aims of the present study is to investigate the effect of air swirl numbers on the isothermal flow field inside the swirl combustor. The flow field can be studied by investigating the effect on the RFZ size, axial velocity distribution, and turbulence intensity.

\subsection{Effect of Swirl Number on Isothermal Flow Filed}

Most combustion systems of practical interest, such as gas turbine combustors, boilers and furnaces, involve large region of recirculating flows. Recirculation zones are created when an adverse axial pressure gradient exceeds the momentum of the fluid flow. These zones provide a heat source, by upstream convection and mixing of hot recirculated combustion products with an incoming fuel and air stream, to serve as a source of continues ignition. The recirculation zone plays an important role in flame stabilization, as it constitutes a well mixed zone of combustion products. This recirculation zone also acts as a source of heat and chemically active species near the burner exit. The recirculation zone is slightly larger than the reverse flow zone and then the two zones can be considered almost the same.

Swirling flows have been commonly used for a number of years for the stabilization of high-intensity combustion processes. In general these swirling flows are poorly understood because of their complexity. The main effects of swirl are to improve flame stability as a result of the formation of toroidal recirculation zones and to reduce combustion lengths by producing high rates of entrainment of the ambient fluid and fast mixing, particularly near to the boundaries of recirculation zones. The trace of points that have zero axial velocity divides the flow field into two zones with respect to the main flow direction. Forward flow zone and reverse flow zone (RFZ) are performed. The trace of these points is named as the boundary of the RFZ $[22,23]$. This can be achieved by determining the positions at which the axial velocity equals zero at different conditions.

\subsubsection{Effect of Swirl Number on RFZ Size}

The air swirl number was changed by using three air swirlers having the same dimensions but differ in the swirler vane angles to provide different swirl numbers of $0.5, .87$ and 1.5. For swirl nu mber of 0.5 (weak swirl), a reverse flow zone of a small size exists which takes the shape of an ellipsoid as shown in Fig. 6a. For swirl numbers of 0.87 and 1.5 (strong swirl) the size of the reverse flow zone increases in diameter with the axial distance from the air swirler and reached a maximum diameter, then decreases at further axial distance. Because the combustor is being opened, the reverse flow zone diameter is slightly increased near the combustor exit. In this case, the reverse flow zone boundaries fill the combustor and the size of the reverse flow zone is increased as the swirl nu mber increases. Also, the bottom of the RFZ is increased in diameter and is more attached to the combustor upstream with increasing the air swirl number.

The comparison between the RFZ with and without combustion shown in Fig. 6.d the RFZ size decrease with combustion, because the thermal expansion took place in the forward flow region resulting in increasing the volumetric flow rate. The thermal expansion occurred also inside the RFZ, but with smaller effect than occurred in the forward flow region.

\subsubsection{Effect of swirl number on axial velocity}

Velocity distribution inside the combustor is very important especially the axial flow velocity inside the reverse flow zone. This is important in keeping the flow of the combustion gases at low velocity that acts as heat source for the incoming fresh mixture of fuel and air. The axial velocity maps are obtained by representing the velocity ranges by colored regions.

The axial velocity maps for different swirl number are shown in Fig. 7. The outer edge of the black regions represents the boundary of the reverse flow zone (locus of zero axial velocity). From this figure, it is shown that the size of the reverse flow zone is increased in length and diameter as the swirl number increases. The levels of the reversed flow velocity inside the reverse flow zone are increased while the levels of the forward axial flow velocity outside it decrease as the swirl number increases.

\subsubsection{Effect of swirl number on turbulence intensity}

Turbulence intensity is defined as the ratio of the rootmean- square of the velocity fluctuations, $u^{\prime}$ to the mean flow velocity, $\mathrm{U}$. 


$$
\begin{gathered}
I=\frac{u^{\prime}}{U} \quad u^{\prime}=\sqrt{\frac{1}{3}\left(u_{x}^{2}+u_{y}^{2}+u_{z}^{2}\right)} \\
U=\sqrt{U_{x}^{2}+U_{y}^{2}+U_{z}^{2}}
\end{gathered}
$$

Percentage turbulence intensity of $(\mathrm{I}=1 \%)$ is considered low, percentage turbulence intensity of (from $1 \%$ to $5 \%$ ) is considered medium and that greater than 10 $\%$ is considered high [18]. It is important to study the turbulence behaviour of isothermal flow inside the combustor.

The effect of swirl number on turbulence intensity maps are shown in Fig. 8. From this figure, it is shown that turbulence intensity levels are increased with increasing the swirl number. The regions of high turbulence intensity move to the combustor upstream as the swirl number increases. Also, increasing the swirl number, the regions of low turbulence intensity increased at the combustor downstream.

\subsection{Effect of Air Swirl Number on Axial Temperature Distributions and Temperature Maps}

The centreline axial temperature distributions, from computations, for different air swirl nu mbers of $0.5,0.87$ and 1.5 are shown in Fig.9.a at AFR of 40 and thermal load of $20 \mathrm{~kW}$. It is observed that, the temperature is increased with the axial distance from the swirler, reached its maximum value and then decreased again with further axial distance. The temperature levels are lower with higher swirl number, because the high temperature regions shift upstream leading to shorter flame length.

From computations, the temperature maps for different swirl numbers of $0.5,0.87$ and 1.5 using the AFR of 40 and thermal load of $21 \mathrm{~kW}$ are shown in Fig. 9.b. At weak swirl $(S=0.5)$, the temperature levels are relatively high and the high temperature regions have larger sizes than those at strong swirl for the same air/fuel ratio. Increasing the air swirl number, high temperatures region shifted upstream direction nearer to air swirler. It can be explained that, increasing the air swirl number, the recirculation zone became stronger, i.e. the recirculated air mass flow rate increased [22] and the mixing rate increased results in small flame size, i.e., shorter flame length but wider flame diameter.

\subsection{Effect of Swirl Number on Species Concentrations (Mole Fractions) Maps}

From computations, the effect of swirl number on the species concentrations (mole fractions) maps for the species $\mathrm{O}_{2}, \mathrm{CO}_{2}$ and $\mathrm{CO}$ at constant AFR of 40 and constant fuel mass flow rate at $0.4 \mathrm{~g} / \mathrm{s}$ (thermal load $=20$ kW) are shown in Figs. 10, 11 and 12, respectively. Most of $\mathrm{O}_{2}$ is consumed in combustion at the upstream section of the combustor. Therefore, $\mathrm{O}_{2}$ has very low levels at the combustor upstream as shown in Fig. 10. The $\mathrm{O}_{2}$ concentrations increased at certain location at the combustor downstream as an indication of the end of the chemical reaction. This location moves upstream for higher swirl numbers. This is due to that the temperature levels and the flame move toward the combustor upstream with increasing the swirl nu mber. Then, $\mathrm{O}_{2}$ concentrations increase with the axial distance from the swirler and reach higher levels for higher swirl nu mbers.

The $\mathrm{CO}_{2}$ concentrations, as shown in Fig. 11 increased with the axial distance until reached maximu $m$ values and then decreased again with further axial distance. The maximu $\mathrm{m}$ values of $\mathrm{CO}_{2}$ concentrations are decreased and move upstream with increasing the swirl number. The $\mathrm{CO}_{2}$ concentrations are nearly constant along most of the combustor centreline for higher swirl number. $\mathrm{CO}$ concentration has higher levels at the combustor middle due to incomplete combustion as shown in Fig. 12. CO maximum is remarkably decreased and shifts upstream with increasing the swirl number. $\mathrm{CO}$ decreased with the axial distance until reaches very low levels at the combustor downstream and at its end.

\subsection{Effect of Inlet Thermal Load on Flame Characteristics}

The effect of changing inlet thermal load of 20,25 and $30 \mathrm{~kW}$ on temperature maps and center line axial temperature distributions, with constant air mass flow rate of $16 \mathrm{~g} / \mathrm{s}$ and constant air swirl number of 0.87 are shown in Fig. 13. It is shown that, by increasing thermal load (i.e. fuel mass flow rate), the fuel momentum increased due to increase in fuel velocity, so that, the high temperatures regions shifted downstream and inward. The axial temperature increased reaches its maximum at the upstream region and then decreased in the downstream region. Increasing the thermal load, the high temperature regions size increased and the flame length increased.

The effect of changing inlet thermal load on $\mathrm{O}_{2}$ concentration (mole fraction) maps, with constant air mass flow rate and constant air swirl number of 0.87 are shown in Fig. 14. It is shown that, by increasing inlet thermal load, the fuel velocity increased, so that, the low oxygen concentration (mole fraction) regions shifted downstream and inward due to increasing the high temperatures regions. The oxygen concentration (mole fraction) decreased at the upstream region as result of the high temperature regions size increased and the flame length increased.

The effect of changing inlet thermal load on $\mathrm{CO}_{2}$ (mole fraction) maps, with constant air mass flow rate and constant air swirl number of 0.87 are shown in Fig. 15. It is shown that, by increasing fuel mass flow rate the high carbon dioxide concentration (mole fraction) regions shifted downstream and inward due to increasing the high temperatures regions. The carbon dioxide concentration (mole fraction) increased at the upstream region.

The prediction distributions of mole fraction for $\mathrm{CO}_{2}$ and $\mathrm{O}_{2}$ show similar trends with temperature, namely the higher the local temperature the stronger the main products formation. This is due to the local temperature 
directly affects the component rates of production and consumption.

$\mathrm{CO}$ concentration (mole fraction) has higher levels at the combustor inlet due to incomplete combustion as shown in Fig. 16. CO maximum is remarkably decreased and shifts upstream with decreasing inlet thermal load i.e. the fuel mass flow rate. CO decreased with the axial distance until reaches very low levels at the combustor downstream and at its end.

\section{CONCLUSIONS}

The computational results of the present work can be summarized as the following:

1. Comparing the measured and the calculated reverse flow zone RFZ sizes using the shear stres s transport (SST) k- $\omega$ model, a reasonable agreement is found.

2. Comparing the measured and the calculated axial and radial temperature distributions at the same operating conditions, a good agreement is found.

3. For weak swirl $\mathrm{S}=0.5$, a RFZ of small size was found which is closed and performed inside the combustor.

4. Increasing the air swirl number, the size of RFZ is increased in length and width and its boundaries fill the combustor.

5. Increasing the air swirl number, the regions of high turbulence intensity move upstream nearer the burner head.

6. Increasing the air swirl number, the high temperature regions size, $\mathrm{CO}_{2}$ and $\mathrm{CO}$ concentrations decreased. But $\mathrm{O}_{2}$ concentration increased.

7.Increasing the thermal load, the high temperature regions size, $\mathrm{CO}_{2}$ and $\mathrm{CO}$ concentrations increased, but $\mathrm{O}_{2}$ concentration decreased.

\section{REFERENCES}

[1] Kontogeorgos, D. A., Keramida, E. P. and Founti, M. A., "Assessment of Simplified Thermal Radiation Models for Engineering Calculations in Natural gasFired Furnace", International Journal of Heat and Mass Transfer Vol. 50, pp. 5260-5268,(2007).

[2] Ilbas, M., "CFD Prediction of Coupled Radiation Heat Transfer and Soot Production in Turbulent Flames", Twenty-Sixth Symposium (International) on Combustion/The Combustion Institute, pp. 23792386, (1996).

[3] Keramida E. P., Liakos H. H., Founti M. A., Boudouvis A. G. and Markatos N. C., "Radiative heat transfer in natural gas - fired furnaces", Int. J. of Hydrogen Energy, Vol. 30, pp. 1113-1126, (2005).

[4] Mustafa Ilbas, "The effect of thermal radition and radition models on hydrogen - hydrocarbon combustion modelling", Int. J. of Hydrogen Energy, Vol. 30, pp. 1113-1126, (2005).

[5] Ilbas, M., Yilmaz I. and Kaplan Y., "Investigation of hydrogen and hydrogen-hydrocarbon composite fuel combustion and NOx emissions characteristics in a model combustor", Int. J. of Hydrogen Energy, Vol. 30, pp. 1139-1147, (2005).

[6] Ibrahim, I. A. and Shabaan, M. M., "Numerical Simulation of Methane Combustion with and without Radiation Models", PSERJ, Vol. 17, No. 1, March (2013).

[7] Carvalho M.G. and Farias T. L., "Modelling of Heat Transfer in Radiating and Combusting Systems", Trans IChemE, Vol. 76, pp. 175 - 184, (1998).

[8] German A. and Mahmud T., "Modeling of NonPremixed Swirl Burner Flows Using a ReynoldsStress Turbulence Closure", Fuel, Vol. 84, pp.583594, (2005).

[9] Weber R., Boysan F., Swithennbank J., and Roberts P.A.R., "Computations of Near Field Aerodynamics of Swirling Expanding Flows", 21st Symposium (International) on Combustion/the Combustion Institute, pp.1435-1443, (1988).

[10] Peng, L. and Zhang, J., "Simulation of Turbulent Combustion and NO Formation in a Swirl Combustor", Chemical Eng ineering Science, Vol. 160, pp.2903 - 2914, (2009).

[11] Khanafer, K. and A ithal, S.M., "Fluid-dynamic and NOx computation in swirl burners ", International Journal of Heat and Mass Transfer, Vol. 54, pp. 50305038, (2011).

[12] Khelila, A., Naji, H., Loukarfi, L. and Mompean, G., "Prediction of a high swirled natural gas diffusion flame using a PDF model ", Fuel, Vol. 88, pp. 374381, (2009).

[13] Jiang, B., Li X., Liang, H. and Uang, G., "Study on NO Formation in CH4/Air Jet Combustion", Chinese J. Chem. Eng., Vol.14, pp.723- 728,(2006).

[14] Xia, J.L., Yadigaroglu, G., Liu Y.S., Schmidli, J., and Smith, B.L., "Numerical and Experimental Study of Swirling Flow in a Model Combustor", International Journal of Heat and Mass Transfer, Vol.4, pp.1485-1497, (1998).

[15] Amani, M. and Nobari, R. H., "An Efficient PDF Calculation of Flame Temperature and Major Species in Turbulent Non-Premixed Flames", Applied Mathematical Modeling, Vol.34, pp. 2223-2241, (2010).

[16] Menter, F.R., "Two Equation Eddy-Viscosity Turbulence Models for Engineering Applications", AIAA Journal, Vol. 32, No. 8, pp. 1598- 1605, (1994)

[17] Fluent Program User Gu ide, Septe mber, (2007).

[18] Gambit Program User Guide, Septe mber, (2007).

[19] Ibrahim, A., Nasser Shelil, Ezz- Eldien, A.H., Mosleh, M. and Farag, T.M.," Effect of secondary air on the flow field inside a gas turbine combustor" PSEJ, Vol. 17, No. 1, (2013).

[20] Sharaf, O.A., "Study of Interaction between annulus Gaseous Fuel Jet and Dual Swirling Air for Vertical Diffusion Flame", Ph.D. Thesis, Port - Said University, (2010). 
[21] Gad, H.M., Farag, T.M., Abdel-Mageed, S.I., Habik S.E. and Ezz- Eldien, A.H. "Kerosene Spray Combustion Characteristics in a Swirl Type Combustor with Normal Secondary Air" PSEJ, Vol. 14, No. 2, pp. 52- 66, (2010)

[22] Farag, T.M., "Reverse Flow Zone Measurement in a Swirl Combustor Model", PSEJ, Vol. 6, pp. 120- 137, (2002)
[23] Gad, H.M., "Experimental Study of Spray Combustion Characteristics in a swirl type combustor", Ph.D. Dissertation, Suez Canal University, Egypt, (2010). 


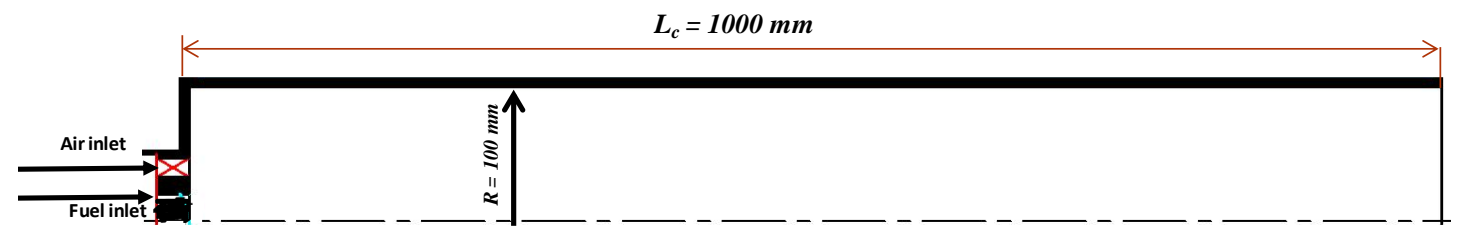

Fig. 1 Geometry of the combustion chamber.

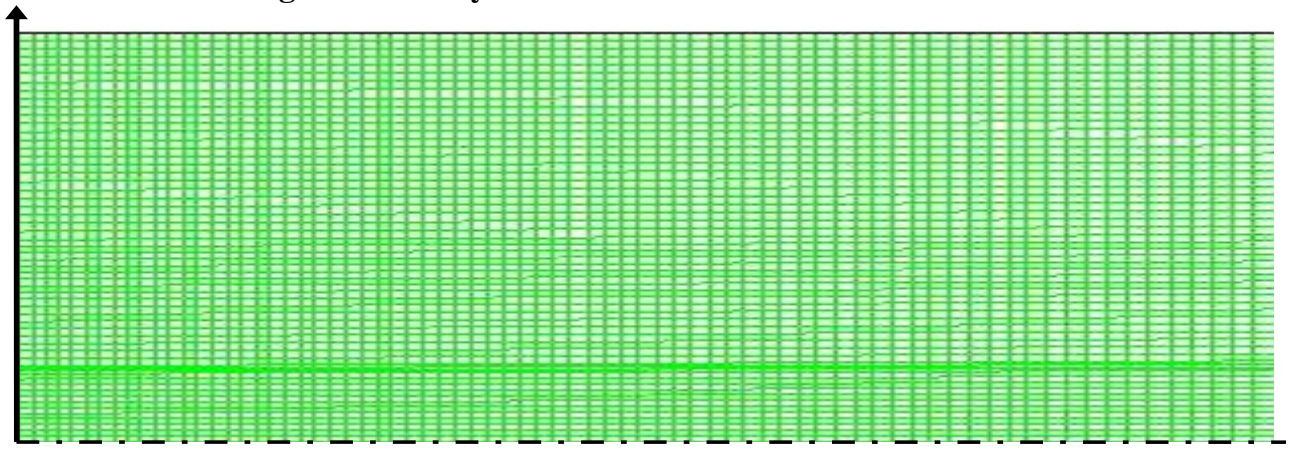

Fig. 2 Part of grid system

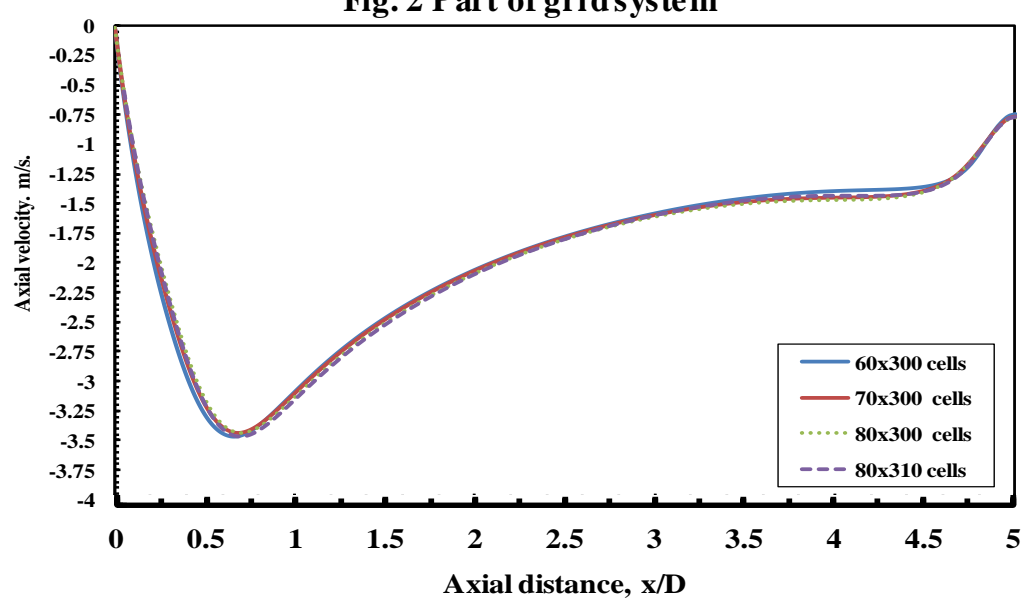

Fig. 3 Axial velocity at different mesh sizes (cold flow)

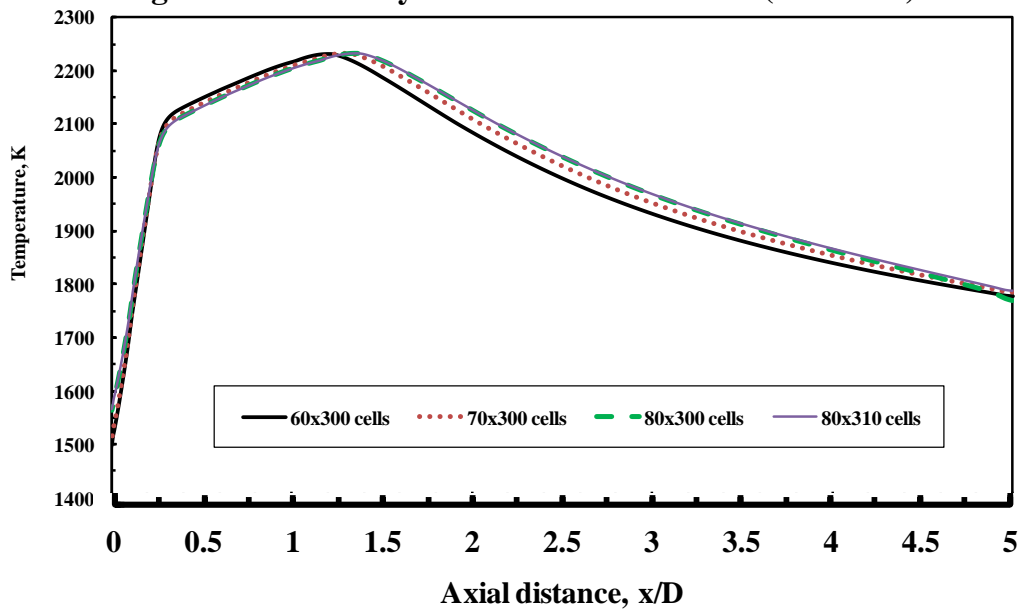

Fig. 4 Axial temperature at different mesh sizes 

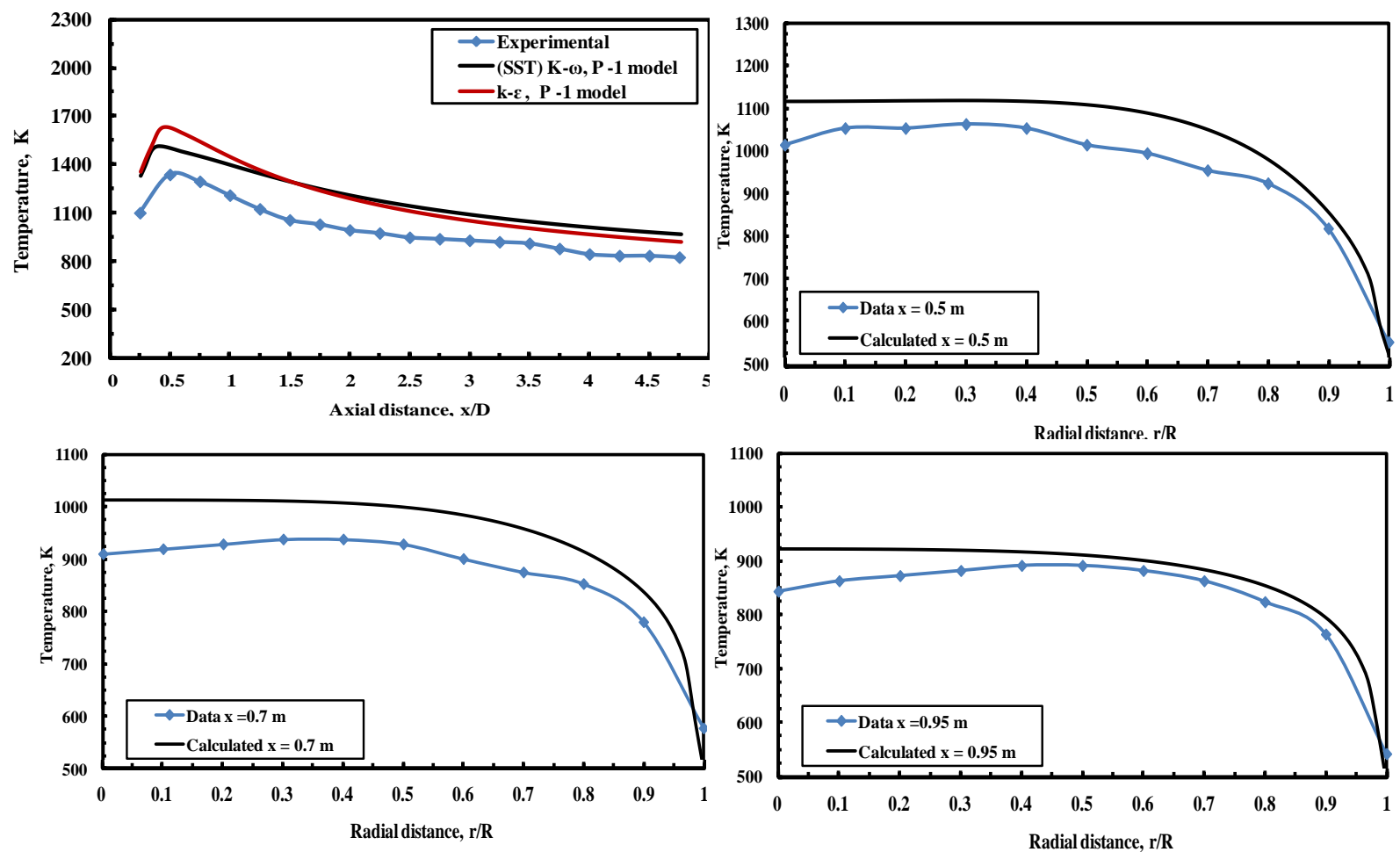

[a] Centerline axial temperature and radial temperature at different axial locations at $\mathrm{S}=0.87$ and

Fig.5 Comparison of calculated and measured values (to be continued on the next page)
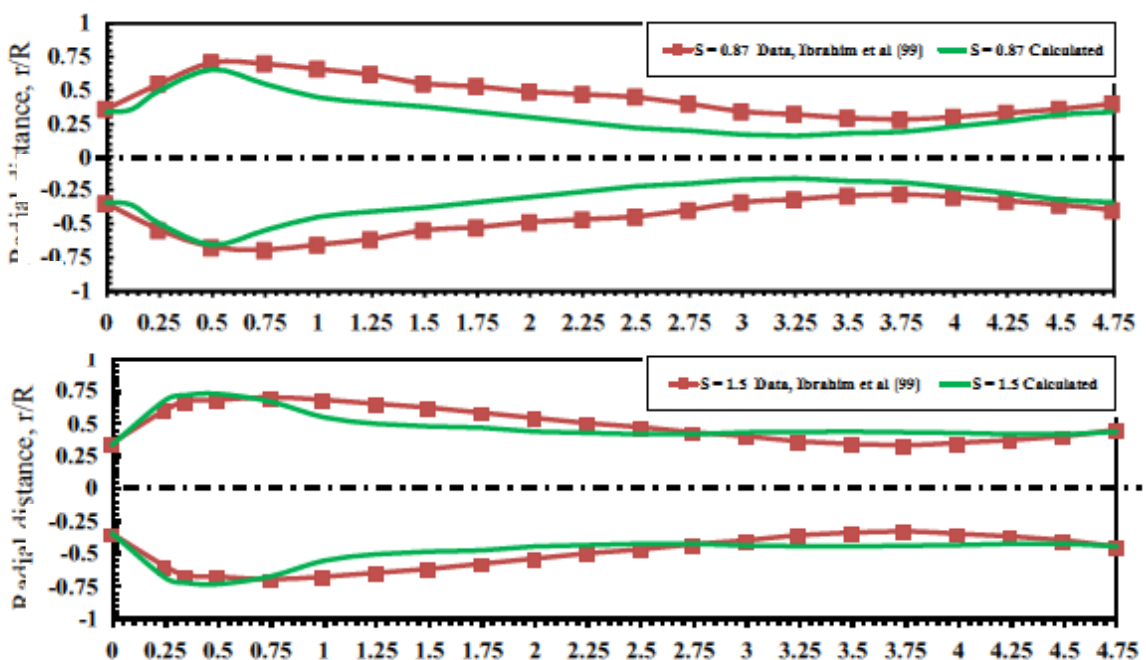

Axial distance, $\mathrm{x} / \mathrm{D}$

[b] Reverse flow zone at $S=0.87,1.5$

Fig.5 Comparison of calculated and measured values 

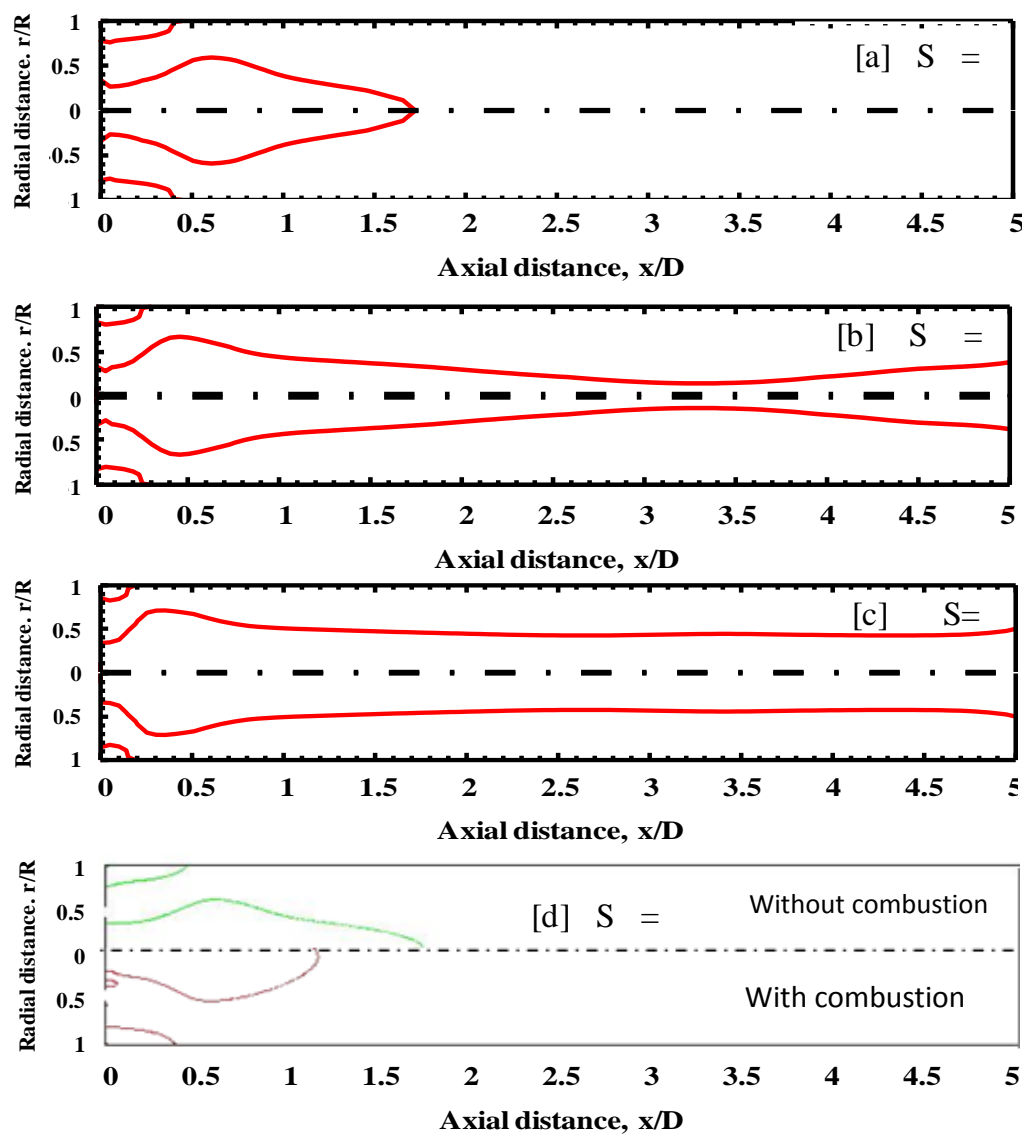

Fig.6 Effect of air $s$ wirl numbers, on RFZ boundaries

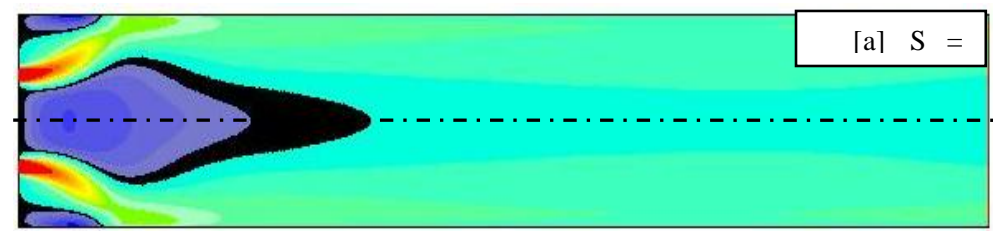

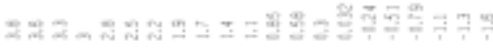

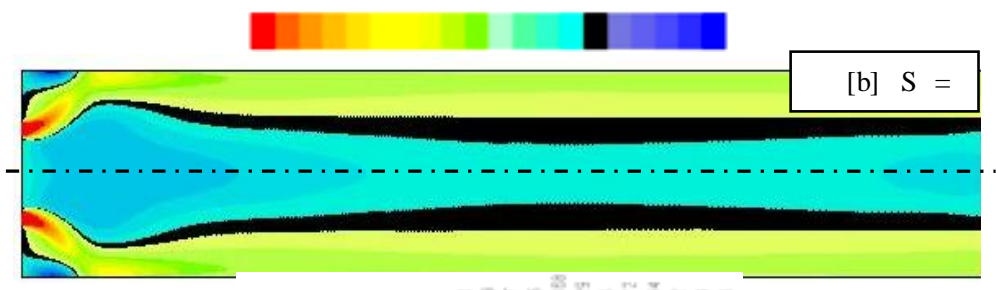

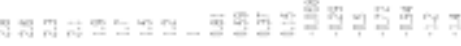

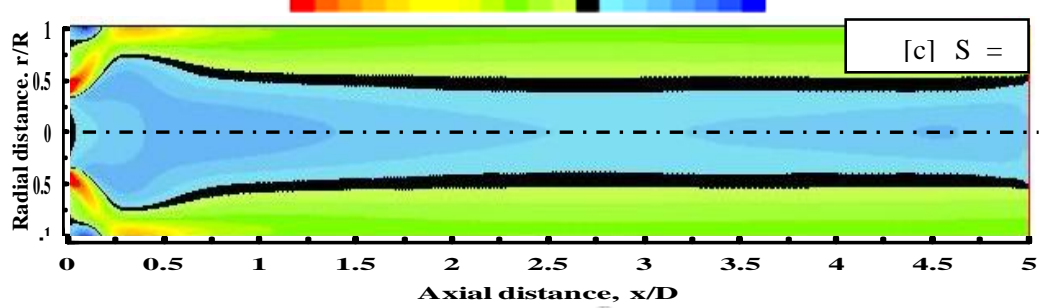

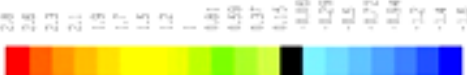

Fig.7 Effect of air $\mathrm{s}$ wirl numbers, on axial velocity maps, $\mathrm{m} / \mathrm{s}$. 

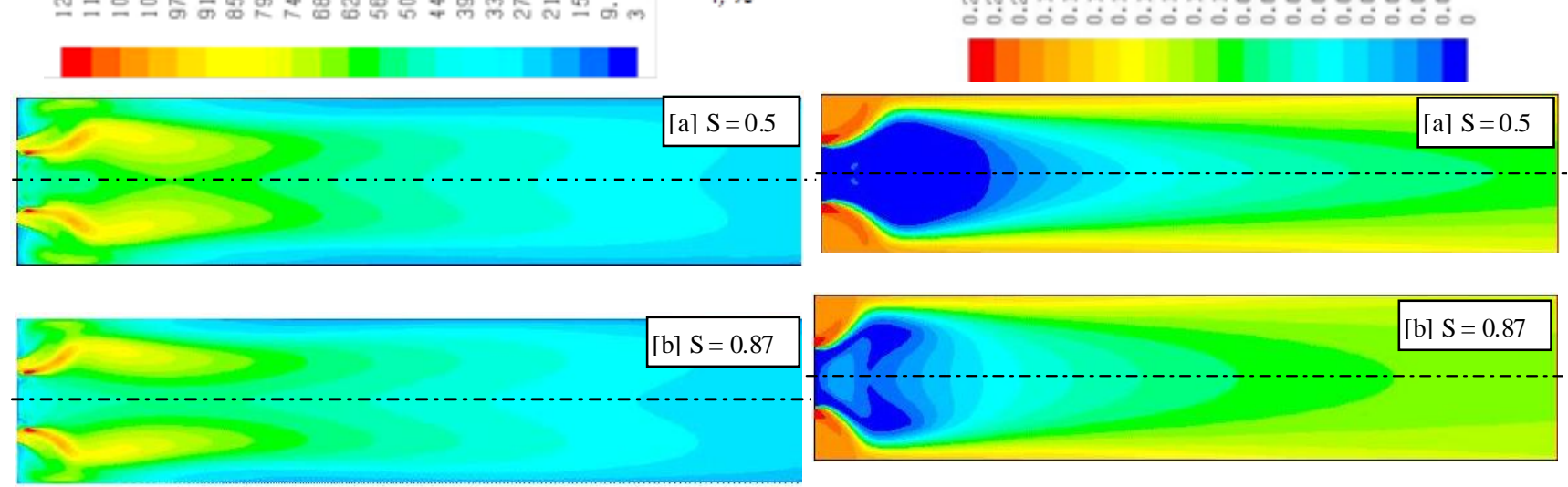

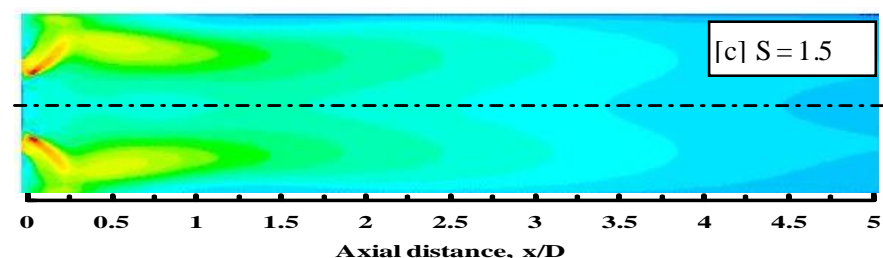

Fig.8 Effect of air s wirl numbers, on turbulence intensity maps, $\%$.
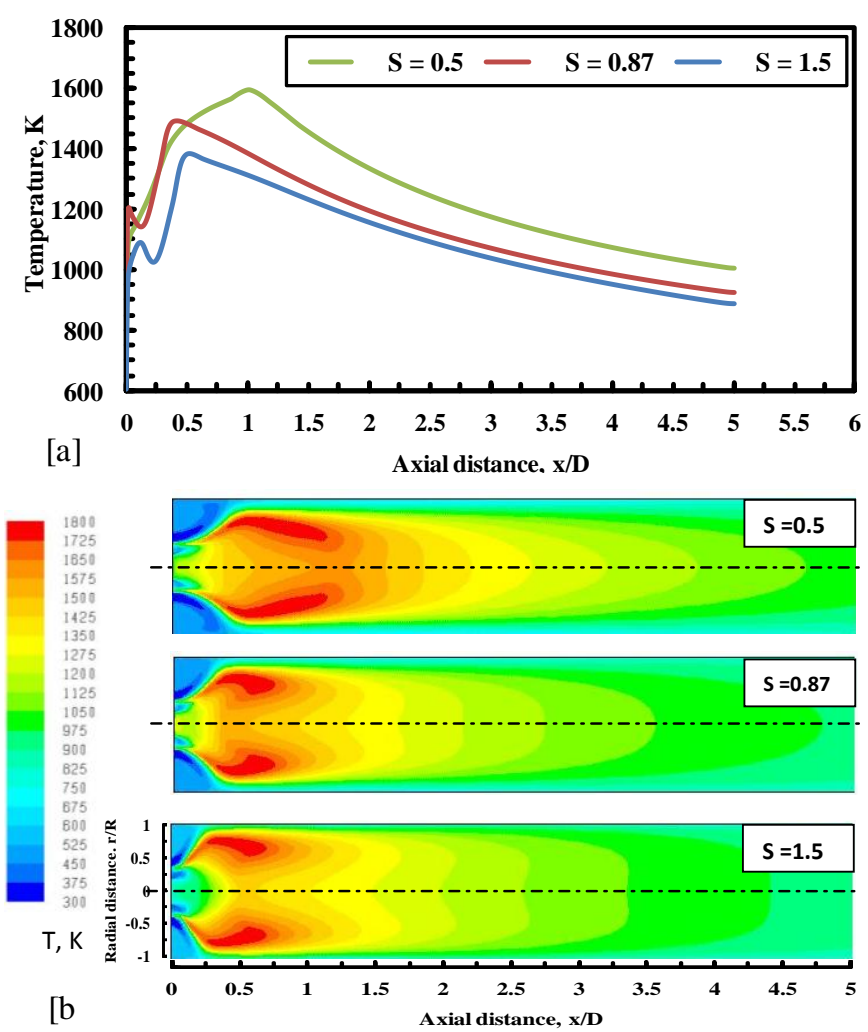

Fig.9 Effect of air $s$ wirl numbers on axial temperature

(a) and temperature maps (b).

[AFR of 40 and thermal load of $20 \mathrm{~kW}$ ]

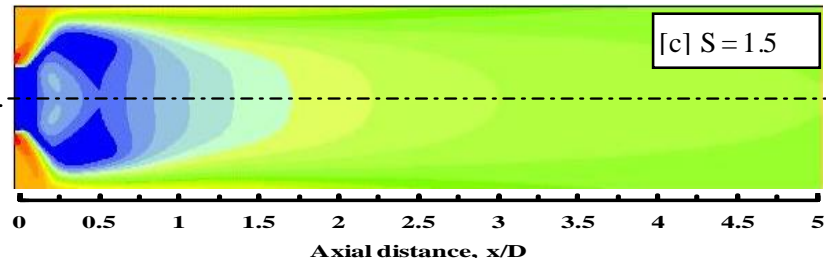

Fig.10 Effect of air $\mathrm{s}$ wirl numbers, on $\mathrm{O}_{2}$ concentrations (mole fraction) maps.

[AFR of 40 and ther mal load of $20 \mathrm{~kW}$ ]
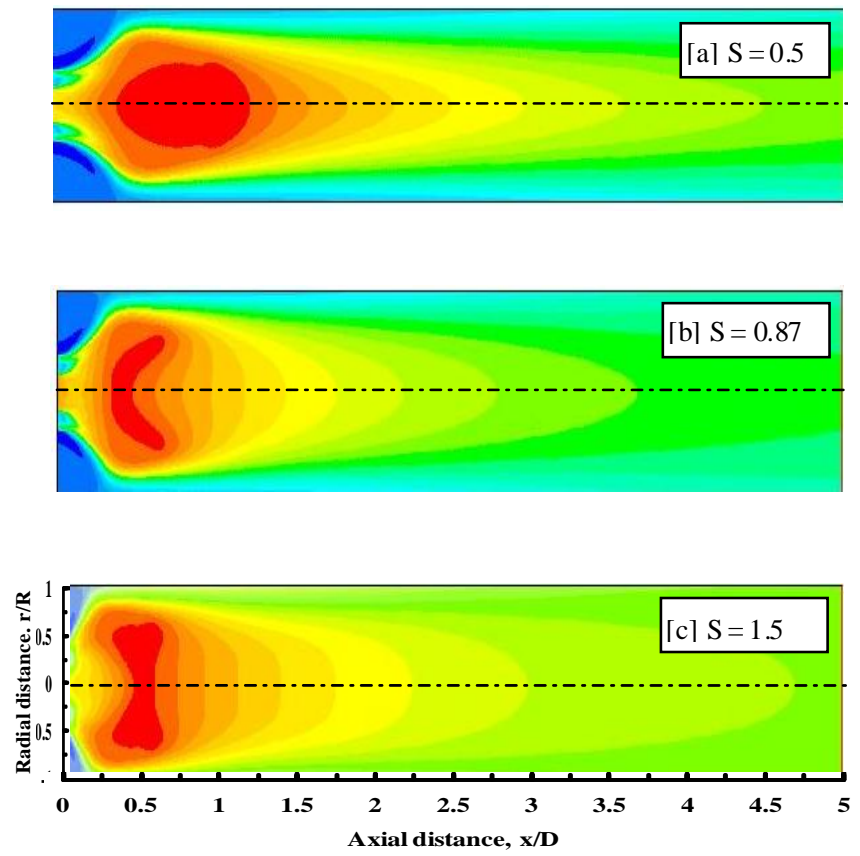

Fig.11 Effect of air $\mathrm{s}$ wirl numbers, on $\mathrm{CO}_{2}$ concentrations (mole fraction) maps. [AFR of 40 and thermal load of $20 \mathrm{~kW}$ ] 


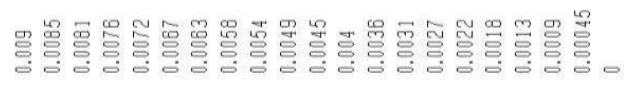

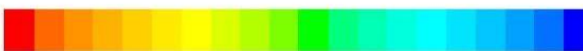
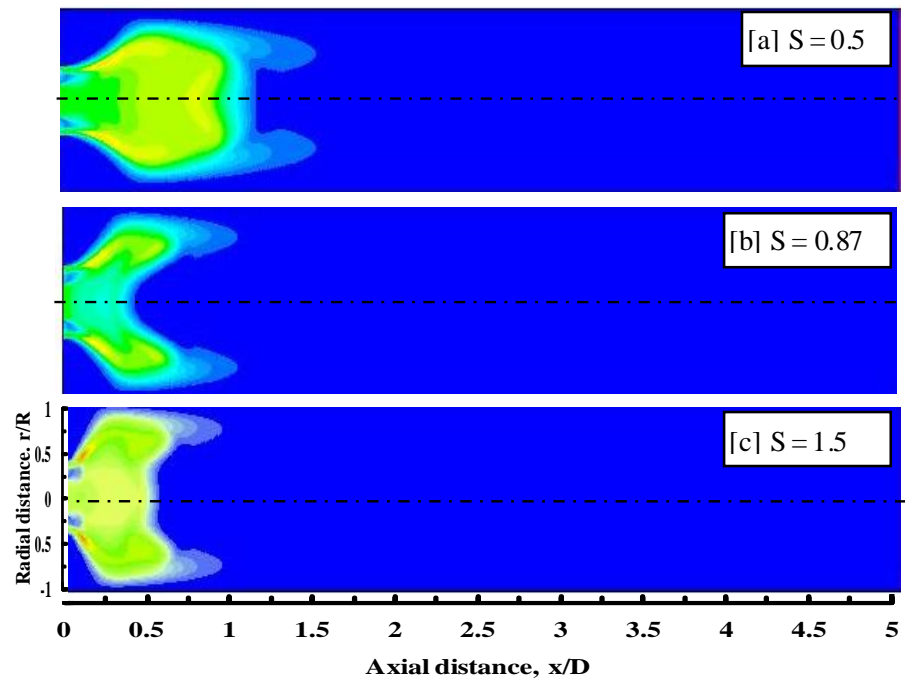

Fig.12 Effect of air $s$ wirl numbers, on CO concentrations (mole fraction) maps.

[AFR of 40 and thermal load of $20 \mathrm{~kW}$ ]
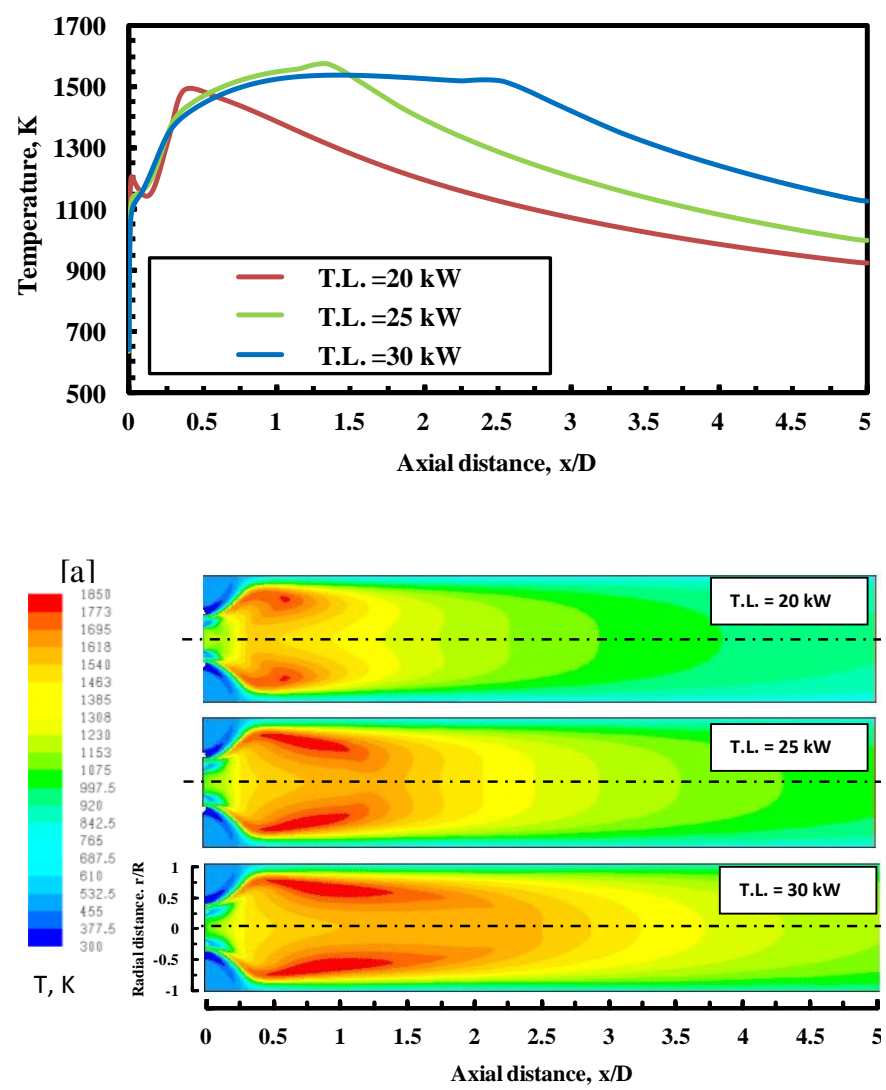

Fig.13 Effect of inlet ther mal load on axial

[b] temperature (a) and temperature maps (b).
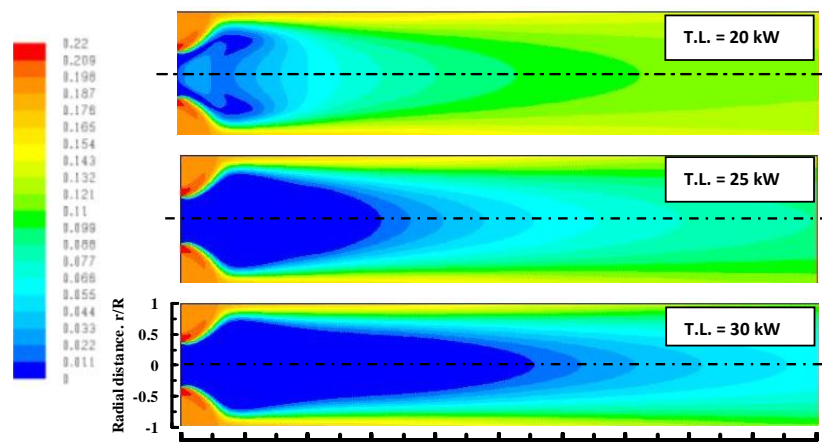

Fig.14 ]
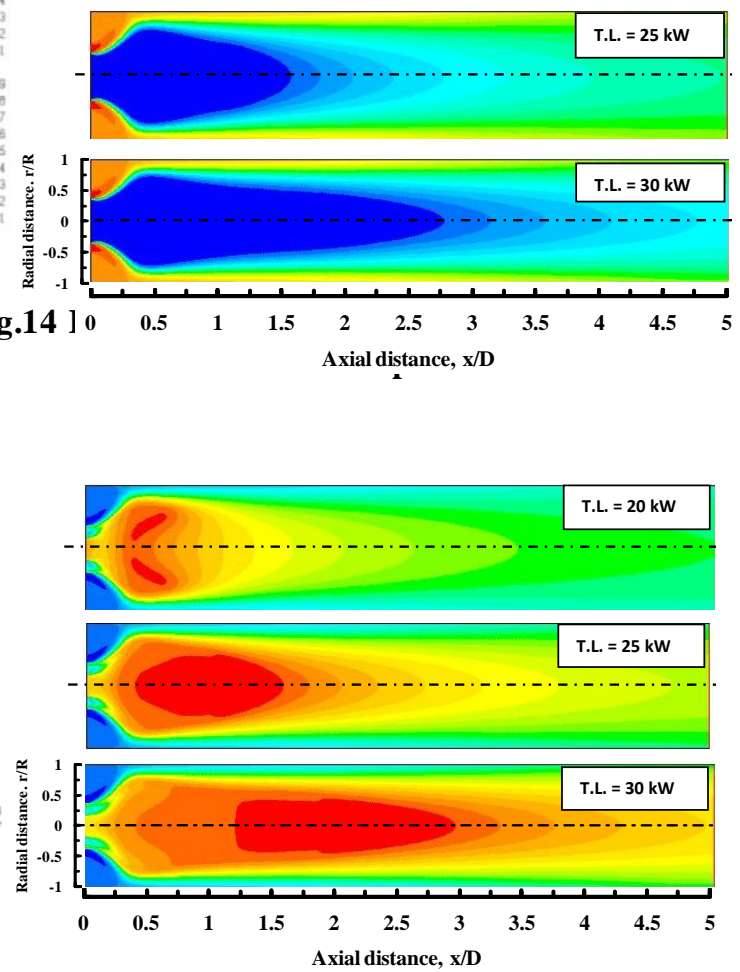

Fig.15 Effect of inlet thermal load on $\mathrm{CO} 2$ concentrations (mole fraction) maps.

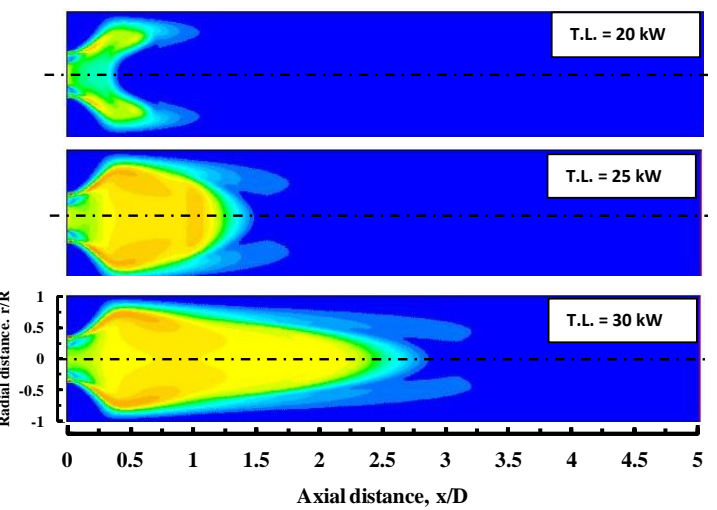

Fig.16 Effect of inlet thermal load on CO concentrations (mole fraction) maps. 